\title{
Achebe's Racial Political Criticism and the Construction of African Subjectivity*
}

\author{
Pengju Qin \\ College of Literature and Journalism \\ Sichuan University \\ Chengdu, China 610065 \\ School of Literature and Media \\ Yulin Normal University \\ Yulin, China 537000
}

\begin{abstract}
Achebe, the father of modern literature in Nigeria, severely criticized Conrad's ethnocentrism and colonial essentialism, pointing out his distorted description of Africa and his disregard for African human nature. Achibe subverted the imperialist narrative with his literary creation, and suggested that Africans must change their perspective and write Africa from within. Achibe's works embody the pursuit of common humanity.
\end{abstract}

Keywords-Achebe; racial political criticism; essentialist criticism; African subjectivity

\section{INTRODUCTION}

Although Conrad's African description shows humanitarian sympathy for Africa, it cannot escape from the overall narrative logic of imperialism, and has a strong racist tendency. Racial discrimination serves imperialist aggression. The essentialism of colonialism propagandizes the universality of civilization, but it is a cheer for the invasion of western civilization. But the narration of colonialism contains the voice of the weak of resistance. The writing of Africa must be entered from the angle of African subject, writing Africa from inside, and it embodies the common humanity pursuit of antiracism.

\section{RACIST CRITICISM OF CONRAD}

In Achebe's literary theory, An Image of Africa: on Racism in Conrad's "Heart of Darkness", Achebe pointed out Conrad's racial centralism. Africans do not have a sense of history. In his view, it is a desire and demand of the westerners. "See Africa as a foil to Europe, a distant and deja vu opposite, in which the advantages of Europe can be revealed." ${ }^{1}$ Conrad's Heart of Darkness is a typical example of this desire and need. Achebe has no doubt of Conrad's great aesthetic contribution.

*[Fund projects]This paper is a stage result to 2016 year Guangxi university young and middle-aged teachers' basic ability enhancement project "Chinua Achebe and African tradition" (KY2016LX261) and Yulin Normal University's 2015 year high level talent project (G20150007) "Chinua Achebe from the perspective of literary and political criticism".

Chinua Achebe,An Image of Africa,Research in African Literatures, Vol. 9,No. 1,Special Issue on Literary Criticism(Spring,1978),p.2.
Conrad is one of the greatest short stories written in English. But this is not the crux of the problem, but the racial ideology embodied in Conrad's text. According to Achebe, Conrad used a comparative approach to place the Thames River in England and the Congo River in Africa at both ends of civilization, the former being the embodiment of civilization and the latter the representative of barbarism. The Thames, though, was once a dark place on earth. But "it conquered the darkness, and now it is light and peace." ${ }^{2}$ Marlowe, the protagonist of the article, went deep into the African hinterland, which undoubtedly implies that civilization invades the center of barbarism and faced the dark abyss itself.

According to Achebe, Conrad's genius lies in the use of beautiful adjectives to "express unspeakable and unfathomable secrets" ${ }^{3}$ which, to many critics, is Conrad's performance as a stylistic. But in Achibe's view, this is a matter of the artist's moral standards and principles. The status and achievement of a writer in the history of literature is determined not only by his artistic ability, but also by his moral level and artistic ability." when a writer pretends to describe situations, events and their effects, it is actually more dangerous for his readers to confuse the reader with emotional words and other tricks than with stylistic problems. Generally speaking, the average reader is alert to and able to resist this shameful practice." ${ }^{4}$

Achebe's criticism of Conrad's moral level is not contradictory to the praise of his artistic level.Because for a great and mature artist, moral level and artistic level are not antagonistic but interdependent. A great literary work, full of the author's emotional attitude, knowledge view and philosophy of life, despite the limitations of the times of the values and ideologies it embodies, but the piece of work must contain the elements that accord with the common emotional state of mankind, that is, human nature, which is the charm of a piece of work. For the work Heart of Darkness, which enjoys

\footnotetext{
2 Chinua Achebe,An Image of Africa, Research in African Literatures,Vol. 9,No. 1,Special Issue on Literary Criticism(Spring,1978),p.3. Chinua Achebe,An Image of Africa, Research in African Literatures,Vol. 9,No. 1,Special Issue on Literary Criticism(Spring,1978),p.3. Chinua Achebe,An Image of Africa, Research in African Literatures, Vol. 9,No. 1,Special Issue on Literary Criticism(Spring,1978),pp.3-4.
} 
a high status in the history of western literature and has been repeated for hundreds of years, its extensive influence and great status are self-evident. It is because of its great influence and outstanding achievements that we should not treat it as ambiguous as ordinary works, but should analyze it seriously and rationally. Only in this way, the status of classical works can be more classical, but also can withstand the test of history. From this point of view, it is reasonable for Achebe to analyze and study Conrad undefined work, which focuses on both artistic and moral level. On the contrary, Conrad's Heart of Darkness does not embody a common human emotion, but a narrow, Western-centric view:

This land does not seem to be the land of the human world. We used to the manacled image of subdued monsters, but over there-you see there-it is a free monster, it is not human, and these people --- No, they do not belong to human. Ah, you know, the worst part of the matter is here-suspected that they do not belong to human. You will slowly come up with the idea. They howl, they jump, they spin, they make all kinds of scary faces, but they make you shiver and creepy, it is precisely what you think they are human-as you are-that they roar so savagely and feverishly, that they are the thoughts of your distant relatives. Ugly. Yes, it is ugly enough. ${ }^{5}$

This is the African image of dehumanization under the domination of Western centralism. So what does a human being look like? In Conrad's view, one was a Western white man like him, the other was a funny black man:

He is a highly educated specimen who can ignite a vertical boiler. He is right under me, telling the truth, seeing him as if you saw a dog in academic breeches, a leather hat, and a dog walking on two hind legs. Months of training have had an effect on this really good guy. He had apparently tried to be fearless, and had bent his eyes to look at the steam pressure gauge and the water gauge-he had a tooth that had been filed flat with a file, and the poor fellow, the cluster of hairs on his head, had been shaved in a strange shape. There are three decorative scars on each cheek. He was supposed to have clapped his hands and stamped his feet on the shore, but he worked hard here, enslaved a strange magic, and filled his mind with advancing knowledge.

Conrad believes that things do not have their place, then there will be a comic phenomenon in the text. According to this logic, Africans should clap their hands in the jungle, clap their hands, shout and howl, and shuttle mysteriously. This is the characteristic African should have. The black mistress of Colz in Achebe, for example, thinks that her appearance not only accords with the development of the plot, but also meets the needs of the western white emotion, and wins the favor of the western white master while she obeys her position very well. The fate of blacks (their status and value) is determined by others, whites, and not by blacks themselves. This fully exposed Conrad's ethnocentrism view: the value of Western civilization is highlighted in the contrast with the Negro, and

[Britain] Joseph Conrad.:The Heart of Darkness, Translated by Xue Shiqi、Zi Liang,Wu Han:Hubei people's Publishing House,2008, p. 45.

[Britain] Joseph Conrad.:The Heart of Darkness, Translated by Xue Shiqi、Zi Liang,Wu Han:Hubei people's Publishing House,2008, p. 46-47. the logic of this contrast is that whites are more civilized than blacks. This presupposes a premise: does a civilization have any value, no humanity, no meaning, because it is at a high level of development, and for other civilizations that are at a low level of development, Non-Western civilization, especially African civilization, has no value or significance, even the basic humanity is lost. Of course, as a man with a profound "liberal British tradition of liberal humanitarianism", the proper expression of sympathy and compassion for other civilizations is humanitarianism. There is no good or bad in human civilization, only the difference between high and low. For the capitalist civilization, which has developed for hundreds of years, its economic, political and cultural development is naturally higher than that of African civilization. In this regard, Conrad regarded the distinction of civilization as the criterion of judging whether civilization was good or bad, which doomed his racial ideological tendency. This led to his deliberate humanitarianism as a cheap and shameless mask to Achebe.

Achebe believed that Conrad had adopted two strategies in describing blacks: "one is to keep the necessary consistency in portraying these dumb savages, and the other is to use their own words as unambiguous evidence of their guilt. This is a wise move." ${ }^{7}$ Conrad took a second approach, without doubt. It is this "rude vague voice", "exchanging short murmurs" that becomes a symbol of black identity, which is what they are and ought to be. They should not speak fluent English, because it does not fit their identity, even if occasionally unexpected, it is the result of Western civilisation. Conrad in Heart of Darkness shows the fuzziness of the black man's inability to speak: howling, grumbling, clapping, haggling, etc., while the occasional black man who learned European civilization to burn steam boilers is as funny as a dog.The Heart of Darkness with its strong ideology and racial tendencies, firmly controls the narrator Marlowe, which inevitably imprints the views of Marlowe as Western centrism. It turns out that the narrator, Marlowe, if he wants to get out of the author's control, will turn around because of his ideology. Even though Marlowe expresses a humanitarian sentiment in Heart of Darkness, this kind of humanitarianism with a strong racial ideology is seen by Achibe as merely a "pretend sympathy."

History shows that African civilization has made great contributions to human civilization. Achebe, for example, says African sculptures have inspired European art and become a source of inspiration for modern Western art as a whole. Conrad's depiction of Africa is like "the relationship between the portrait of Dorian Gray and Gray-a master who must unload his physical and psychological flaws onto a carrier so that he can walk straight and chic." ${ }^{8}$ Africans are not a casual curtain and background. They are people. "They are not angels, nor people without evolution - only people, they are often

[Britain] compiled by Bart Gilbert:Post-colonial

criticism,Translated by Yang Naiqiao, Mao Rongyun and Liu

Xuming,proofreaded by Yang Naiqiao,Beijing:Beijing University Press,2001,p.186.

[Britain] compiled by Bart Gilbert:Post-colonial criticism, Translated by Yang Naiqiao, Mao Rongyun and Liu Xuming,proofreaded by Yang Naiqiao,Beijing:Beijing University Press,2001,p.192. 
extremely smart and often create examples of success in life and social development." ${ }^{9}$ The seriousness of the problem is that, with the exception of Conrad, most Westerners see nothing wrong with Conrad's narrative, they read Heart of Darkness as a great and outstanding work, and generations of Westerners regard it as the preferred classic because they believe that beyond the great aesthetic achievements of the work the description of human nature and events is authentic and does not differ beyond their ideologies. As Achebe puts it: "Conrad witnessed and condemned imperialist exploitation, but could not see the racism that made imperialist exploitation. Victims of racist rumours have had to live in the inhuman state of racism that perpetuates them for centuries." ${ }^{10}$ Western white racial ideology, like Conrad's black and white contrasts, embodies white people's sense of superiority over blacks, even genius such as Conrad. This unconscious racism permeates every character in the novel. Conrad is not without a condemnation of imperialism, but it is no help than the absurd depiction of black inhumanity embodied in Conrad's text.

Said pointed out in Culture and Imperialism that no matter how far the narrator Marlow deviated from the subject and how difficult his journey was, he eventually reached the end of the voyage, the heart of Africa. The story gives a powerful theme: "European imperialist control and will in Africa, or in African issues." 11 According to the saying, Conrad was different among colonial writers and related to his own colonial identity. He was not a native English writer, but was the person of Poland. His colonial immigration status made him particularly sensitive and disgusted with colonialism in his novels, but compared with the overall atmosphere and power of imperialist control at that time. His Heart of Darkness "is imperialist from a political and aesthetic point of view." ${ }^{12}$ Imperialist ideology prevented Conrad from seeing the existence of consciousness beyond it, and did not allow Conrad to think so.

According to Said, besides the narrative clues of colonialism and racism, there is another anti-colonial narrative clue, that is, the description of "darkness" in Heart of Darkness. Dark has its own independence; it can penetrate into the center of the empire. Conrad's limitation is that he saw the brutal exploitation of imperialism, but could not foresee its disintegration. "Darkness" for Conrad is only a barbaric and devouring force of mystery, not an anti-colonial force of confrontation that will eventually dispel colonialism and dispel the myth of ethnocentrism. Apparently Conrad's perception has not risen to this level. The merit of said lies in the dark power in Heart of Darkness, which foresees the anti-colonial power

9 Chinua Achebe:An Image of Africa, Research in African Literatures, Vol. 9,No. 1,Special Issue on Literary Criticism(Spring,1978),p.13.

10 [Britain] compiled by Bart Gilbert:Post-colonial criticism, Translated by Yang Naiqiao, Mao Rongyun and Liu Xuming,proofreaded by Yang Naiqiao,Beijing:Beijing University Press,2001,p.193.

11 [America] Edward .W. Said:Culture and imperialism, Translated by Li Kun,Beijing:Life, reading, new knowledge, Sanlian Bookstore,2007,p.29.

12 [America] Edward .W. Said:Culture and imperialism,Translated by Li Kun,Beijing:Life, reading, new knowledge, Sanlian Bookstore,2007,p.30. and torrent in the future. Therefore, this explains why Conrad cannot walk out of the myth of ethnocentrism.

\section{ESSENTIALIST CRITICISM OF COLONIALISM}

Albert Schwarzer said that Africans are indeed my brothers, but only my younger brother. That means that Africa must be humbled and get all the opportunity to learn from Europe. The ultimate consequence is that Africa will serve Europe like God, and once the praise of Europe becomes inappropriate, Africa should be self deprecating. The logic of colonialism is Europe has brought favors and civilizations to Africa. If it cannot be seen, it is "ingratitude". Achebe is such an "ungrateful" person who is deeply abhorred by colonialists. But in fact, the criticism of Western civilization by Achebe does not mean that he denies Western civilization, nor does it mean his full appreciation of the African civilization, it is a factual attitude.

Charles Larson, in The Rise of African Fiction, put forward the question of universality of novels, and argues that universality was the lack of reference to Africa. In Achebe's view, "the works of Western writers always automatically give universality. Others, however, must work hard to achieve this universality." ${ }^{13}$ Achebe hoped that this so-called universality will not become a synonym for narrow western centralism, but a true embodiment of an inclusive world mind. The colonialists were always persuasive in their invasion by denigrating the colonial people's lack of responsibility and moral indecency for the superiority of their civilization. In the final analysis, this ideology, which contains racism, is a justification for colonialism, which has done disgraceful deeds in history, and it is the mask of racism that seeks justice for the essence of this aggression.

In the view of the colonists, "when you talk about the development level of a nation, you can determine their overall development and find an undisputed and clear position for them on the human evolutionary ladder. In other words, you have the power to explain all their physical and spiritual life."14 The colonists provided the basis and guidelines for the artistic level of the colonial people because of backward social production status. Therefore, the Christian civilization believed that it had the responsibility and obligation to save this barbarous and backward civilization. The colonists did not like the people who were too serious and "solemn", but preferred the obedient colonies to the people, Writers such as Achebe are objects of colonialists' efforts to suppress and criticize. Achebe believes that the writer should have the ability to change the world and the courage to change the world. It should be like a national fighter and a warrior, to show some kind of offensive "solemn". The artist has the responsibility to change the surroundings of our circumference through art. The novel is not the unique style and privilege of the West, for a writer such as achebe, changing the image and fate of the colonialists is the mission and sense of responsibility of novelists.

\footnotetext{
13 Chinua Achebe:Home and Impediments:Selected Essays, New York,A Division of Randow House, 1990,p.76.

14 Chinua Achebe:Home and Impediments:Selected Essays, New
} York,A Division of Randow House, 1990,p.83. 
Both post-colonial discourse power analysis and Marxist post-colonial political and economic analysis focus on racial, class and gender issues. The problem of race is the legacy of colonial rule, which confronts the sovereign state / colony, colonizer / colonized person, and attempts to look down upon the colony and the colonized person from the perspective of another. This is also Said's "Orientalism" of Westerners, to prove the nobility of their race and the advanced civilization, while the colonized people are lowly, civilization is backward. This kind of image of the other in the eyes of the westerners constructed in the self-imagination is not the real East, but a false construction to satisfy the needs of the westerners. It is the embodiment of the greedy desire and hegemonic thought of the westerners. Of course, the text of promoting colonial aggression should be criticized without mercy, but even more obscure is a kind of imperceptible colonial thinking in the works of a group of famous Western writers. Because of their great influence, these writers have done more harm to Africa, because it is in the unperceived admiration and overall acceptance of these writers' texts that the image of Africa is shaped and solidified.

For example, in Conrad, Defoe, Swift, Kipling, Rushdie, Foster and other writers, the colonial and colonized' image is mysterious, vague, uncertain. In particular, Conrad, who writes about Africa, is a prehistoric continent with wild silence. Speechless Africans howl, and as civilizational watchers, they never know what Africans are doing and what they need to do. In their eyes, Africa is a terrible desert, Africa is a meaningless being, the most terrible and sad thing, "We and they are relatives." Conrad's profound psychoanalysis and illusory language mask colonial thinking in Africa. While appreciating Conrad's beautiful prose and fluent style, people do not think about the discriminatory description of Africa, but unconsciously accept the description of Africa. And it accumulates as a collective unconscious of the majority of people who understand Africa, study Africa, and has basic information and evidence on Africa, in order to provide ignorance of Africa and so-called knowledge at the right time. It was with Conrad that Westerners began to learn a great deal about Africa, but it was not true, but colonial. A large number of historians, anthropologists, linguists, and archaeologists in the West have even replicated this colonial thinking, even the famous philosopher Hagel thought that "Africa has no history". Therefore, it is an urgent task for African writers to criticize colonialism in writing colonial African literature.

In his literary theory, Achibe rejected colonialism without mercy and exposed the racism in Conrad's Heart of Darkness. This led to widespread criticism of colonialism and racism in classical Western literature, and it was from Achebe that postcolonial theorists were inspired. At the same time, Achebe is also doing another job, that is, from Africans to write about Africa. The construction of African subject identity must change the perspective and view Africa from the African perspective. To understand a true Africa and its people, we must go deep into Africa and write from the depths of the African soul.

\section{THE CONSTRUCTION OF AFRICAN SUBJECTIVITY}

The human nature of Africa must first construct Africa's subjectivity. The subjective construction of Africa must be written in Africa from the perspective of the main body of the African people, into the interior of Africa to write Africa, African writing by Achebe embodies a common pursuit of humanity in anti racism.

\section{A. Writing African Africa from Within}

Subjectivity is originally a philosophical term, it is with the development of philosophy and ups and downs. From the beginning of being the subject of the world, people have the subjectivity. To talk about human being is to talk about human subjectivity, which is the symbol of human self-consciousness and rational thinking awakening. Achebe not only in literary creation, but also in social practice, acts as the vanguard of the construction of the subject. These social activities also profoundly affected the construction of literary subjectivity.

For Achebe, his African subject shaping came from his assimilation of the western rational subjective concept, thus reversing the colonial subject as the colonized subject. "The people of the colonial countries strive for their status as historical subjects by force or by any other means", ${ }^{15}$ thus giving attention to African native literature, as silence, and depriving the vast majority of the African people of the right to speak to preserve the dignity of Africa.

Achebe describes the heroes of the tribe from the perspective of Africa. "Collaspe" depicted Ogonkavo, the Ibo warrior, has won the respect of the villagers by his hard work, but then he accidentally killed the son of an elder and was fined seven years for not returning home. In the meantime, the white man infiltrated the village, and when he returned, everything changed. His power and position were no longer possessed, and in the end he hanged himself when he was about to be arrested for killing the white messenger in the conflict with the white man. No peace is a sequel to disintegrate. The article told the story of Augunkavo's grandson, Obi, who returned to work after receiving a scholarship to study abroad. Obi was a meritorious, idealistic, and just young man, but was hit by a series of secular forces when he returned home. Obi's girlfriend Clara, because of the traditional customs, the two could not be together in the end. Under a series of blows, Obi began to follow the tide of the world, but the secular cannot tolerate him, he was finally arrested for bribery.

Arrow of God depicted the tragedy Ezeulu, the great igbo priest, in order to maintain his authority and status, and whirl between the white and the villagers. He was a high priest in six villages, but his stubbornness caused discontent. He disagreed with the villagers who argued for a traditional war to fight for land. He told the white man the fact that caused the white people to judge the land to another area. For indirect rule, the white people were attracted to the high priest Izeulu, but their arrogant attitude angered Izeulu. He failed to comply with the

15 [Britain] Ellke Boehmer:Colonial and Post-colonial Literature. Translated by Sheng Ning et al. Shenyang: Liaoning Education Press, 1998, p 
orders undefined by white men, leading to his arrest. While he was in custody, he was mired in painful thinking that the consequences were caused by villagers. So he figured out the means of revenge. At the cassava Harvest Festival, he delayed announcing the coming of the Harvest Festival on the grounds that the old cassava had not been eaten, while the cassava had only two, saying that according to the will of God, he could not eat it casually. The high priest, who had the power to plant and harvest, in this way firmly grasped its status and dignity, but what he did not realize was that the villagers had failed to abide by this ancient law, and the heathen had taken the opportunity to promise that, under the infiltration of Christianity, As long as they believe in Christ, they can not only escape punishment, but also secure to harvest cassava. It was a great irony that the High Priest had sent his third son, Oduk, to the Christian Church as a spy. Obika, the second son, died of physical exhaustion at a funeral ceremony. In the end, the high priest, Ezeulu, went mad with grief and anger. In Arrow of God, we can see not only the present situation of the tribal traditional arrows in the western culture, but also the complete collapse of the arrows of the vengeance of the Ezeulu, the high priest, in front of the tribal people and in the face of the white people of the West.

Anthills of the Savannah described the tragedy of a fictional Kagan country, old friend Same, Chris and Ikem. One of the protagonists of the story, Beatrice, presented a complex relationship with the three men, both as a national staff member and in a tit-for-tat environment with them. For Chris and Ikem, she disagreed with either of them, maintaining her own independence and maintaining good friendships with them. It can be said that she was the real protagonist in the work. Sam served as President Kagan, Chris as Minister of Department of Public Information, and Ikem succeeded Chris as editor of the State Gazette. Because of his frequent reactionary remarks, Same, as president, ordered Chris to stop his editorial work. But Chris was embarrassed because he had no such power, including the entire government. Eventually, Ikem was murdered by a totalitarian government that was increasingly ruled by an iron hand. Chris had a sense of danger and fled to Abasson with the help of University of Barcelona Student Union President Emmanuel etc. Chris stopped a policeman trying to insult a passing girl on the road, but they shot him dead. In the end, the historical responsibility fell to Beatrice, whose work ended in her naming of Elva's children. The novel takes the protagonist of each chapter as the first person and is no longer an omniscient narrative style, firmly grasps the reader's reading psychology In addition, the description of the environment and psychology is obviously more mature.

In Achebe's novels, the protagonist's position is no longer the background character in Africa, but the center and protagonist of the story. Let's take Achebe's famous book, "collapse," as an example, and compare it with Joyce Carey's Mr. Johnson and Conrad's Heart of Darkness to see how the protagonist changes. Mr. Johnson described a black Johnson. As European hired, he kowtowed to the Europeans, but the tragedy of not being seen by whites. In spite of his woeful position to win white trust, Johnson enjoyed it all the time. The poor man in front of the white man turned and despised his fellow blacks. Eventually, he was sentenced to death for stealing and killing. Mr. Johnson described a lot of black people, but most of them are sentimental, have no emotional experience, have only intuition and instinct. Whites, on the other hand, are rational, thoughtful, and calm. Mr. Johnson is nominally written, but he only exists as an embellishment of the white man, and we cannot find any meaning in his existence except to please the white master. Similarly, in Conrad's Heart of Darkness, Conrad described blacks in the same way. The domesticated savage black man was described by Conrad as a "domesticated species," who, like a dog, could still mimic people in trousers and walk on two legs, which was surprising. It is written that black people have no humanity, and that animal-like existence exists in a large number of sentences.

Contrast Cary and Conrad, Achebe's Things Fall Apart presents a black society that is full of life. First, the protagonist of the story is a hero, not a puppet. Okonkwo became rich by his industry. He earned the title for his bravery in wrestling, thus winning the respect of the tribesmen. Unyielding to his fate, he killed the white messenger in the knowledge that he could not defeat the white man, and finally committed suicide. This tragic spirit, like the heroes depicted in ancient epics, has the spirit of unyielding and the precious quality of defending dignity to the death.

Secondly, black people have their own characteristics, emotions and emotions, not indifferent animals. They have compassion and love. Okonkwo was not perfect, he had a heart of fear, "he feared failure, fear of weakness. His fear of failure and weakness is deeper than his fear of demons, of capricious gods and monsters, of the forest, of the bloody red claws of malicious nature." ${ }^{16}$ During the week of Peace he scolded his wife and defied God's will. And when Okonkwo killed his adopted boy, Ikemefuna, for days, "his eyes were red and fierce, like a mouse being caught by the tail and falling to the ground." "He felt like a drunken giant walking on the feet of a mosquito." ${ }^{17}$ When his favorite daughter, Ezinma, fell ill, he tried every means to heal her, fully demonstrating his sense of responsibility as a father.

Finally, black people have rich cultural and human characteristics. In Things Fall Apart, we see all kinds of festival celebrations and wedding and funeral ceremonies. People love music and dance, have strong religious beliefs, hold various religious rituals, use witchcraft to cure the sick and save people. People eat kola nut and cassava porridge, paste, drink palm wine, and propose with agate shells. When Obierika's daughter was married, the scene was lively, pretentious and extravagant. The black people was hospitable, drawn with a white line, and served with kola nut. Whenever a major event, in the square struck Ogene ${ }^{18}$ for democratic consultation. There are, of course, ugly vices, such as the abandonment of twins, untouchability, tribal struggles, violent

\footnotetext{
16 [Nigeria] Chinua Achebe: Things Fall Apart, Translated by Gao Zongyu, Chongqing:Chongqing Publishing House, 2009,p.13.

17 [Nigeria] Chinua Achebe: Things Fall Apart, Translated by Gao Zongyu, Chongqing:Chongqing Publishing House,2009,p.56.

18 A kind of gong in Africa.
} 
feuds, and so on. But it is a mature society, not a world of barbarism, culture and humanity in the West.

\section{B. The Common Humanity of Anti-racism}

Reading Achebe's work, we have a clear understanding of African culture and of Africans, of humanity, of civilization, of human life like the rest of the world. This is what the story itself gives us, and behind it is the ideology of ethnocentrism that counteracts the ethnocentrism of people like Joyce Cary and Conrad, who inspired Achebe to write. Achebe was determined to describe the story of Africa because he lived in an environment that prompted him to connect the pieces of life into a meaningful and continuous world. He had a story to tell, which he would have told without Joyce Caryb and others. The reason for this is that Achibe lived in a double cultural environment in which he could not choose from childhood: African traditional culture and Western Christian culture.

His parents were devout Christians, and Achebe had been educated in church schools since childhood, which determined his Christian cultural background. Achebe, on the other hand, was born in Africa, and his surroundings have taught him tradition. But when he was young, he could not feel the tear brought by the two cultures, which were well integrated into one. On the one hand, he read the Bible and sang hymns with his parents with interest; on the other hand, he casually went to the pagan home to receive their gifts, which the Christians thought unreasonable. The result of this embrace of the two cultures, in addition to the acumen and richness of the soul embodied in Achebe, is also determined by the culture of Ibo, which nurtured him. "The Iberians advocate duality rather than singularity. The existence of an object must be accompanied by something else." ${ }^{19}$ This objective sense of distance and free and open cultural thought determine that Achebe's view of human nature is dialectical, not essential. Africa has a maxim: "one man is a man because of others." In his view, "our humanity depends on the humanity of all of us." No man or group can be alone. We will only be better than other animals as a whole, otherwise we will be completely opposite." ${ }^{20}$ This universal human thought enabled him to overcome the essentialism of thinking.

But we see in the Things Fall Apart and so on is an African - oriented human nature writing, the protagonist is Africans, they have the principles and tracks of their own life, and the face of the westerners is obscure. Does this mean that he has fallen into the trap of essentialism? Saeed said on this question: "in Deconstruction practice, you have to realize that you will have essential behavior in any case. So you can think strategically about essentialism. It is not a way to exist as a thing, but as a way that people must adopt when they criticize something. " ${ }^{21} \mathrm{He}$ was involved in the deconstruction of western centralism. He answered with his actual creative

19 Chinua Achebe,The Education of a British-Protected

Child:Essays,New York:Alfred A. Knopt,2009,PP.5-6.

20 Chinua Achebe,The Education of a British-Protected

Child:Essays,New York:Alfred A. Knopt,2009,P.166.

21 [America] Edward. W. said,The collection of Saeed's selfselection,Translated by Xie Shaobo et al.Beijing:China Social Sciences Press, 1999 ,p.131. behavior. In the criticism of weapons, he had to choose the weapon of criticism. Achebe's strategy on this issue is to remain sober critical consciousness like Said. In the construction of the traditional culture of the African nation, he took a dialectical and objective attitude, not only to sing the song for the nation, but to analyze its shortcomings and to point out the inferiority, thus providing a permanent criticism and spiritual direction for the national traditional freshmen. This understanding comes from three aspects: one is the care of Western civilization, which gives him an objective view of the traditional reference of our nation. A certain sense of distance made him have an objective judgment of the national tradition and Western civilization.

The second aspect comes from his life experience, where he grew up in an Igbo society governed by change, and everything here gave him a sense of change. The Igbo have no monarchs and hold democratic consultations when important things happen. Everything is dialectical and changing, and Achebe is deeply influenced by this view of thinking.

Third, as a writer and scholar, he has a profound understanding of Western civilization and African tradition, and the writer undefined responsibility, sense of mission and the objective justice of the scholar urge him to make a correct, factual judgment. As a writer, he spoke for Africans and for national traditions. As a scholar, he wants to treat the two civilizations objectively and fairly and speak with facts.

\section{CONCLUSION}

Achebe firmly believes that literature can change the world and repair the heart. Achebe tells us a true Africa in literary texts. The purpose of the text is to counterattack the Western colonial discourse, to rebuild the subjectivity of Africa and a common pursuit of human nature.

\section{REFERENCES}

[1] Chinua Achebe,An Image of Africa, Research in African Literatures, Vol. 9,No. 1,Special Issue on Literary Criticism(Spring,1978),p.2.

[2] Chinua Achebe,An Image of Africa,Research in African Literatures, Vol. 9,No. 1,Special Issue on Literary Criticism(Spring,1978),p.3.

[3] Chinua Achebe,An Image of Africa,Research in African Literatures, Vol. 9,No. 1,Special Issue on Literary Criticism(Spring,1978),p.3.

[4] Chinua Achebe,An Image of Africa, Research in African Literatures, Vol. 9,No. 1,Special Issue on Literary Criticism(Spring,1978),pp.3-4.

[5] [Britain] Joseph Conrad,The Heart of Darkness, Translated by Xue Shiqi、Zi Liang,Wu Han:Hubei people's Publishing House,2008, p. 45. [英] 约瑟夫 - 康拉德: 《黑暗的心》, 薛诗绮、智量译, 武汉: 湖北人民出版社, 2008 年，第 45 页。

[6] [Britain] Joseph Conrad,The Heart of Darkness, Translated by Xue Shiqi、Zi Liang,Wu Han:Hubei people's Publishing House,2008, p. 4647. [英] 约瑟夫 - 康拉德: 《黑暗的心》, 薛诗绮、智量译, 武 汉：湖北人民出版社， 2008 年，第 46-47 页。

[7] [Britain] compiled by Bart Gilbert,Post-colonial criticism,Translated by Yang Naiqiao, Mao Rongyun and Liu Xuming,proofreaded by Yang Naiqiao,Beijing:Beijing University Press,2001,p.186. [英]巴特・吉 尔伯特编撰: 《后殖民批评》, 杨乃乔、毛荣运、刘须明译, 杨乃 乔校, 北京: 北京大学出版社, 2001 年, 第 186 页。

[8] [Britain] compiled by Bart Gilbert,Post-colonial criticism,Translated by Yang Naiqiao, Mao Rongyun and Liu Xuming,proofreaded by Yang Naiqiao,Beijing:Beijing University Press,2001,p.192. [英] 巴特・吉 
尔伯特编撰: 《后殖民批评》, 杨乃乔、毛荣运、刘须明译, 杨乃 乔校, 北京: 北京大学出版社, 2001 年, 第 192 页。

[9] Chinua Achebe, An Image of Africa,Research in African Literatures, Vol. 9, No. 1,Special Issue on Literary Criticism(Spring,1978),p.13.

[10] [Britain] compiled by Bart Gilbert,Post-colonial criticism,Translated by Yang Naiqiao, Mao Rongyun and Liu Xuming,proofreaded by Yang Naiqiao,Beijing:Beijing University Press,2001,p.193. [英]巴特・吉 尔伯特编撰: 《后殖民批评》, 杨乃乔、毛荣运、刘须明译, 杨乃 乔校, 北京: 北京大学出版社, 2001 年, 第 193 页。

[11] [America] Edward .W. Said,Culture and imperialism,Translated by $\mathrm{Li}$ Kun,Beijing:Life, reading, new knowledge, Sanlian Bookstore,2007,p.29. 美] 爱德华・W. 萨义德: 《文化与帝国主 义》, 李琨译, 北京: 生活・读书・新知三联书店, 2007 年, 第 29 页。

[12] [America] Edward .W. Said,Culture and imperialism, Translated by Li Kun,Beijing: Life, reading, new knowledge, Sanlian Bookstore, 2007,p.30. [美] 爱德华・W. 萨义德: 《文化与帝国主义》，李 琨译, 北京: 生活・读书・新知三联书店, 2007 年, 第 30 页。

[13] Chinua Achebe, Home and Impediments: Selected Essays, New York, A Division of Randow House, 1990,p.76.

[14] Chinua Achebe, Home and Impediments: Selected Essays, New York, A Division of Randow House, 1990,p.83.

[15] [Britain] Elleke Boehmer,Colonial and Post-colonial Literature, Translated by Sheng Ning et al. Shenyang: Liaoning Education Press, 1998, p. 4. [英] 艾勒克 - 博埃默: 《殖民与后殖民文学》, 盛宁 等译, 沈阳: 辽宁教育出版社, 1998 年, 第 4 页。

[16] [Nigeria] Chinua Achebe,Things Fall Apart,Translated by Gao Zongyu, Chongqing:Chongqing Publishing House, 2009,p.13.

[17] [Nigeria] Chinua Achebe,Things Fall Apart,Translated by Gao Zongyu, Chongqing:Chongqing Publishing House,2009,p.56.

[18] Chinua Achebe,Things Fall Apart,Translated by Gao Zongyu, Chongqing:Chongqing Publishing House, 2009,p.13. [尼日利亚] 钦 努阿・阿契贝: 《瓦解》, 高宗禹译, 重庆: 重庆出版社, 2009 年, 第 13 页。

[19] Chinua Achebe,Things Fall Apart,Translated by Gao Zongyu, Chongqing:Chongqing Publishing House, 2009,p.56. [ [尼日利亚] 钦努阿・阿契贝: 《瓦解》, 高宗禹译, 重庆: 重庆出版社, 2009 年, 第 56 页。

[20] [America] Edward. W. said,The collection of Saeed's selfselection,Translated by Xie Shaobo et al.Beijing:China Social Sciences Press,1999,p.131. [美] 爱德华・W. 萨义德: 《赛义德自选 集》, 谢少波等译, 北京: 中国社会科学出版社, 1999 年, 第 131 页。 